\title{
Hematopoietic stem cell transplantation for autoimmune diseases in the time of COVID-19: EBMT guidelines and recommendations
}

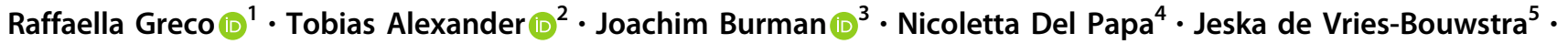 \\ Dominique Farge $^{6,7,8}$ - Jörg Henes ${ }^{9} \cdot$ Majid Kazmi $^{10} \cdot$ Kirill Kirgizov $^{11}$ - Paolo A. Muraro $\mathbb{D}^{12}$ - Elena Ricart ${ }^{13,14}$. \\ Montserrat Rovira ${ }^{15}$ - Riccardo Saccardi ${ }^{16}$ - Basil Sharrack ${ }^{17,18} \cdot$ Emilian Snarski $\oplus^{19,20,21}$ - Barbara Withers ${ }^{22}$.

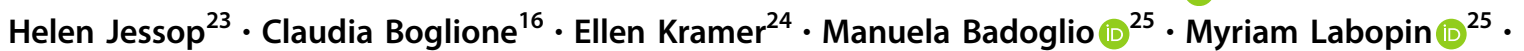 \\ Kim Orchard ${ }^{26} \cdot$ Selim Corbacioglu ${ }^{27} \cdot$ Per Ljungman $\mathbb{\circledR}^{28} \cdot$ Malgorzata Mikulska ${ }^{29}$. Rafael De la Camara $\mathbb{B}^{30}$. \\ John A. Snowden $\mathbb{1}^{23,31}$. On behalf of the European Society for Blood and Marrow Transplantation (EBMT) \\ Autoimmune Diseases Working Party (ADWP), Infectious Diseases Working Party (IDWP), Pediatric Working Party \\ (PWP), Joint Accreditation Committee of the International Society for Cellular Therapy (ISCT) and EBMT (JACIE), \\ EBMT Nurses Group and Patient Advocacy Committee
}

Received: 28 February 2021 / Revised: 17 April 2021 / Accepted: 21 April 2021 / Published online: 24 May 2021

(c) The Author(s) 2021. This article is published with open access

\begin{abstract}
Coronavirus disease-19 (COVID-19), caused by Severe Acute Respiratory Syndrome Coronavirus 2 (SARS-CoV-2), represents one of the biggest challenges of 21st century, threatening public health around the globe. Increasing age and presence of co-morbidities are reported risk factors for severe disease and mortality, along with autoimmune diseases (ADs) and immunosuppressive treatments such as haematopoietic stem cell transplantation (HSCT), which are also associated with adverse outcomes. We review the impact of the pandemic on specific groups of patients with neurological, rheumatological, and gastroenterological indications, along with the challenges delivering HSCT in adult and pediatric populations. Moving forward, we developed consensus-based guidelines and recommendations for best practice and quality of patient care in order to support clinicians, scientists, and their multidisciplinary teams, as well as patients and their carers. These guidelines aim to support national and international organizations related to autoimmune diseases and local clinical teams delivering HSCT. Areas of unmet need and future research questions are also highlighted. The waves of the COVID-19 pandemic are predicted to be followed by an "endemic" phase and therefore an ongoing risk within a "new normality". These recommendations reflect currently available evidence, coupled with expert opinion, and will be revised according to necessary modifications in practice.
\end{abstract}

\section{Introduction}

Since the onset of the COVID-19 pandemic [1], various reports detail its clinical manifestations and outcomes [2-6]. Delivery of HSCT requires maintenance of a complex infrastructure, quality assured according to a range of accreditation standards, and severely impacted during the pandemic. Under normal circumstances, autologous and allogeneic HSCT are performed in patients with severe ADs after careful balance of benefits and risks, with

Raffaella Greco

greco.raffaella@hsr.it

Extended author information available on the last page of the article consideration of other non-transplant treatment options [7-10]. The majority of such patients have chronic diseases, which impact on quality of life and may shorten life expectancy. Transplant regimens used in autologous HSCT for ADs are generally more immunosuppressive than those used for other indications [8], and patients often receive immunomodulatory treatments prior and after HSCT. Immunocompromised patients are at elevated risk of complications from SARS-CoV-2 [11-17]. However, it remains uncertain whether conventional immunosuppressive treatments, glucocorticoid usage, and/or targeted-biologic disease modifying therapies (DMTs), are advantageous or detrimental [18].

As a basis for our guidelines and recommendations, we appraise the impact of the pandemic on patients with ADs, 
including non-HSCT treatments, along with the challenges delivering HSCT during the initial waves of the COVID-19 pandemic. The current phase of the COVID-19 pandemic is predicted to be followed by an "endemic" phase and therefore an ongoing risk within a "new normality". There is therefore a need within the community for guidelines to restart HSCT programs, whilst maintaining quality and cautiously balancing risks and benefits against alternative treatment options in each AD. These guidelines and recommendations should be read in conjunction with general and AD-specific guidelines from European Society for Blood and Marrow Transplantation (EBMT) [19, 20]. They aim to provide useful information and general principles for national and international organizations and local clinical teams across relevant $\mathrm{AD}$ specialties whilst complementing guidelines and recommendations issued by other specialist societies.

\section{Methods}

The recommendations (Tables 1-3) provided in this "living document" reflect currently available evidence, COVIDrelated guidelines regularly updated by EBMT [20], relevant $\mathrm{AD}$ specialists and HSCT societies, policies and procedures produced by national authorities as well as local and institutional policies, coupled with expert opinion from an international multidisciplinary team (MDT). Evidence was sourced from PubMed searches of original observations and key reviews, including the previous EBMT guidelines [7, 8, 19-21], and, where relevant, recent congress presentations.

As per other EBMT guidelines and recommendations, level of evidence for the efficacy of autologous HSCT in $\mathrm{ADs}$ is systematically classified in three categories of recommendations where HSCT should be considered (S/ CO/GNR - see Tables 2 and 3, and related footnotes) $[7,21]$. Strength of evidence supporting the assignment of a particular category of recommendations is graded (levels I, II, and III) based on consideration of health benefits, side effects, and risks and balanced against the non-HSCT options. Clinical priority, as determined by a relevant MDT [22], has been classified as high, intermediate, or low, while the COVID-19 Alert Level [23, 24] as very low, low, moderate, high, or very high (see Tables 2 and 3, and related footnotes).

\section{Preliminary analysis of the impact of COVID-19 outbreak on HSCT programs for ADs}

Across the EBMT registry, we investigated the impact of the COVID-19 outbreak on transplant activity for ADs. When the transplant activity for ADs during the pandemic was compared with the corresponding time in 2019, a total of 116 patients received an autologous HSCT between March and December 2020, while 242 patients received autologous HSCT the previous year in the same time frame (Fig. 1). Compared to 2019, transplant activity for ADs decreased by $52 \%$. Nevertheless, indications remained unchanged with multiple sclerosis (MS) and systemic sclerosis (SSc) comprising $80 \%$ of transplants in ADs reported to the EBMT in 2020, being HSCT an integral and standard-of-care part of their treatment algorithms [21].

\section{General recommendations for restarting HSCT program in ADs}

All AD patients considered for HSCT should be carefully discussed at the local MDT meeting, with input from HSCT and $\mathrm{AD}$ specialists and consideration of alternative treatments [20]. If HSCT treatment is in the best interests of patients, established treatment protocols for AD should be followed, as per guidelines and evidence-based appraisals.

The ongoing learning curve will need to be extended into longer-term modifications in clinical practice, with the "restoration and recovery" or "reset" periods, during which SARS-CoV-2 minimization can be completed, aiming to overcome any further "resurges" and peaks. Consequently, HSCT programs must be ready to rapidly adapt to this change following the course of the pandemic and be able to prioritize the process of delivering HSCT according to clinical urgency [25], depending on virus, hospital, patient, and HSCT-related factors (Table 1) [22, 25].

Nurses have a key role in explaining all the related precautions, including strict adherence to local policies relating to visiting. Clear written information for patients and caregivers should be provided, including measures to minimize the risk of infection, and need for a dedicated caregiver, having low risk of SARS-CoV-2 exposure, in the first months after HSCT. Patients intending to travel abroad for HSCT should consider carefully what arrangements are in place to minimize the risk but also the provision of care post discharge, especially if there are any potential travel restrictions between the country of treatment and their home.

Since the COVID-19 situation varies substantially between and within countries, we recognize that centers are mandated to follow guidelines, policies, and procedures decided by national authorities as well as local and institutional policies. Special consideration should be made when the home base or country of the patient is different from the HSCT center, where R numbers [26] and clinical practice, including in relation to precautions, may differ. As such arrangements will be individualized, there is a recommendation that patients are systematically discussed by and between MDTs at both sites, and, after the HSCT procedure, there is a clear communication between the 


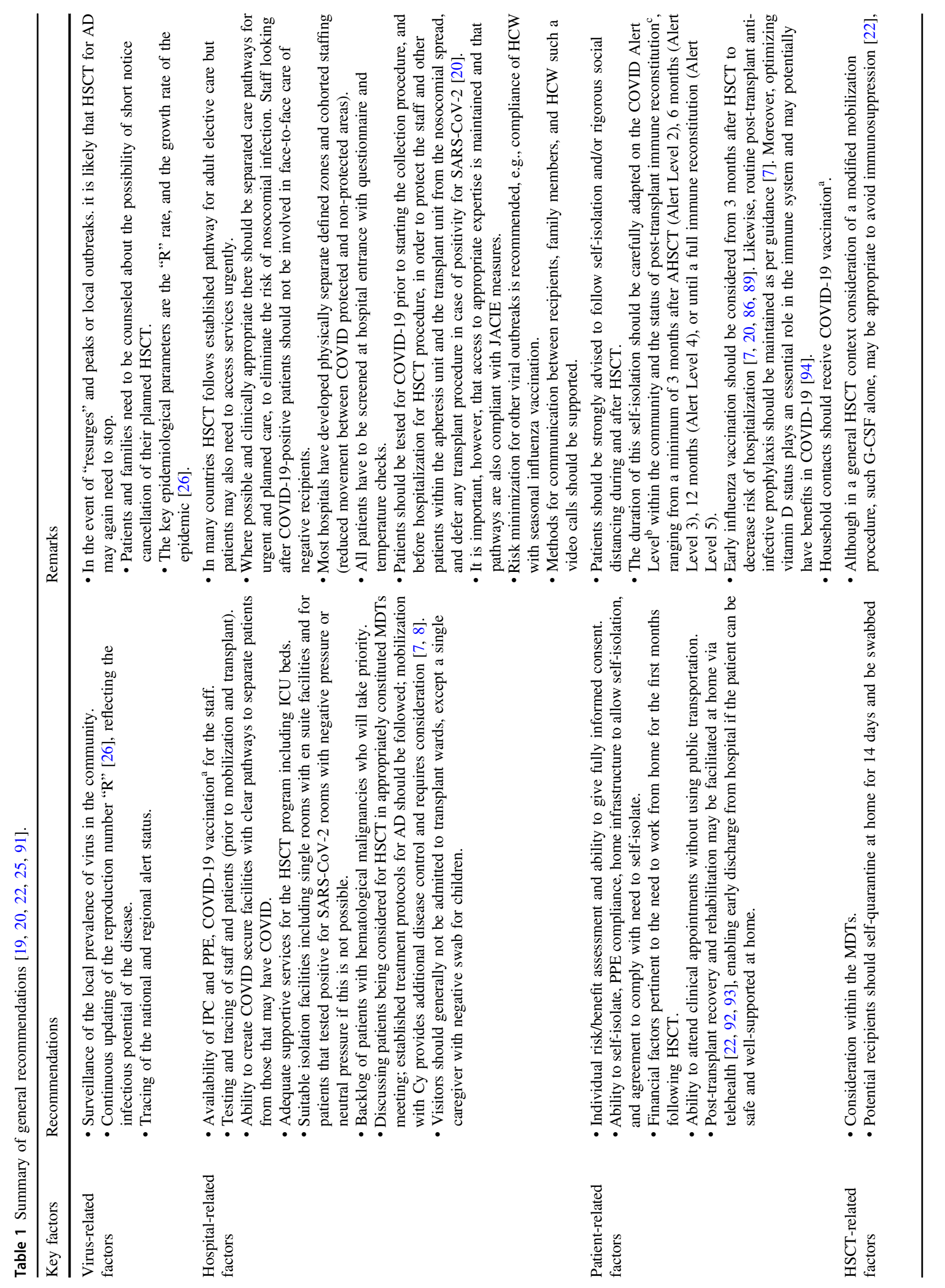




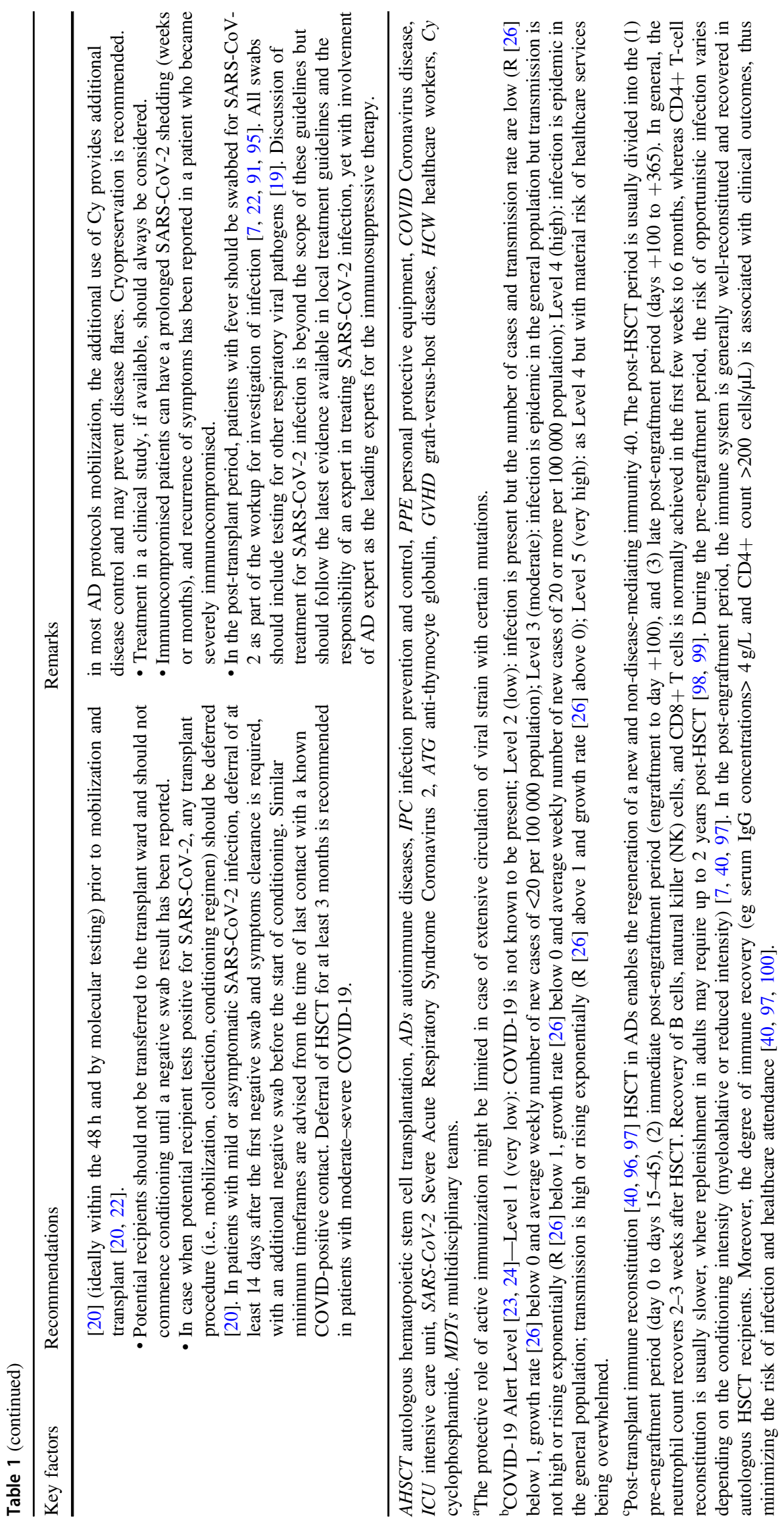


Table 2 Summary of recommendations for autologous HSCT in neurologic autoimmune diseases in the time of COVID-19.

\begin{tabular}{|c|c|c|c|c|}
\hline & $\begin{array}{l}\text { Strength of evidence and } \\
\text { recommendations [7] }\end{array}$ & $\begin{array}{l}\text { Clinical } \\
\text { priority [22] }\end{array}$ & $\begin{array}{l}\text { Maximum COVID-19 } \\
\text { Alert Level }[23,24]\end{array}$ & $\begin{array}{l}\text { Minimum setting } \\
\text { required [7] }\end{array}$ \\
\hline $\begin{array}{l}\text { Highly active relapsing remitting MS } \\
\text { failing DMTs }\end{array}$ & $\mathrm{S} / \mathrm{I}$ & $\begin{array}{l}1 \\
2 \\
3\end{array}$ & $\begin{array}{l}4 \\
3 \\
2\end{array}$ & $\begin{array}{l}\text { Registry } \\
\text { Prospective studies } \\
\text { Prospective studies }\end{array}$ \\
\hline $\begin{array}{l}\text { Aggressive MS not previously treated } \\
\text { with a full course of DMT }\end{array}$ & $\mathrm{CO} / \mathrm{II}$ & $\begin{array}{l}1 \\
2\end{array}$ & $\begin{array}{l}3 \\
2\end{array}$ & $\begin{array}{l}\text { Registry } \\
\text { Registry }\end{array}$ \\
\hline $\begin{array}{l}\text { Progressive MS with active } \\
\text { inflammatory component }\end{array}$ & $\mathrm{CO} / \mathrm{II}$ & 2 & 2 & Registry \\
\hline $\begin{array}{l}\text { Progressive MS without active } \\
\text { inflammatory component }\end{array}$ & GNR/III & N/A & N/A & N/A \\
\hline Pediatric MS & $\mathrm{CO} / \mathrm{II}$ & $\begin{array}{l}1 \\
2\end{array}$ & $\begin{array}{l}3 \\
2\end{array}$ & $\begin{array}{l}\text { Registry } \\
\text { Registry }\end{array}$ \\
\hline Treatment-resistant CIDP & $\mathrm{CO} / \mathrm{II}$ & 2 & 2 & Registry \\
\hline Treatment-resistant NMOSD & $\mathrm{CO} / \mathrm{II}$ & $\begin{array}{l}1 \\
2\end{array}$ & $\begin{array}{l}3 \\
2\end{array}$ & $\begin{array}{l}\text { Registry } \\
\text { Registry }\end{array}$ \\
\hline Treatment-resistant SPSD & $\mathrm{CO} / \mathrm{II}$ & $\begin{array}{l}1 \\
2\end{array}$ & $\begin{array}{l}3 \\
2\end{array}$ & $\begin{array}{l}\text { Registry } \\
\text { Registry }\end{array}$ \\
\hline $\begin{array}{l}\text { Rare IMNDs and treatment-resistant } \\
\text { systemic ADs }\end{array}$ & $\mathrm{CO} / \mathrm{II}$ & 2 & 2 & Registry \\
\hline
\end{tabular}

Strength of evidence of clinical efficacy [7]—Grade I: evidence from at least one well-executed randomized trial, Grade II: evidence from at least one well-designed clinical trial without randomization; cohort or case-controlled analytic studies, Grade III: evidence from opinions of respected authorities based on clinical experience. Recommendations ${ }^{7}: S$ standard of care, $C O$ clinical option, GNR generally not recommended.

Clinical priority (as determined by a relevant multidisciplinary team) [22] — 1: high, delaying the HSCT procedure presents a high risk of disease progression, morbidity or mortality, 2: intermediate, there is a risk of disease progression or clinical complications if HSCT is delayed significantly, 3: low, the risk of disease progression or clinical complications if HSCT is significantly delayed is low.

COVID-19 Alert Level [23, 24]—Level 1 (very low): COVID-19 is not known to be present; Level 2 (low): infection is present but the number of cases and transmission rate are low (R [26] below 1, growth rate [26] below 0 and average weekly number of new cases of less than 20 per 100000 population); Level 3 (moderate): infection is epidemic in the general population but transmission is not high or rising exponentially ( $\mathrm{R}$ [26] below 1, growth rate [26] below 0 and average weekly number of new cases of 20 or more per 100000 population); Level 4 (high): infection is epidemic in the general population; transmission is high or rising exponentially ( $\mathrm{R}$ [26] above 1 and growth rate [26] above 0); Level 5 (very high): as Level 4 but with material risk of healthcare services being overwhelmed.

Setting [7]— prospective studies: randomized controlled trials (RCTs) and other clinical trials, including RAM-MS, STAR-MS, NET-MS, COAST, BEAT-MS, or prospective non-interventional studies (NIS) including OMST [6]. Registry: reporting data to EBMT registry (or equivalent international registry, e.g., CIBMTR).

$H S C T$ autologous hematopoietic stem cell transplantation, $M S$ multiple sclerosis, $D M T$ disease modifying therapies, $C I D P$ chronic inflammatory demyelinating polyradiculoneuropathy, NMOSD neuromyelitis optica spectrum disorder, SPSD stiff person spectrum disorder, IMNDs immunemediated neurological disorders, ADs autoimmune diseases, CIBMTR Center for International Blood and Marrow Transplant Research, N/A not applicable.

transplant center and the receiving site and their clinicians for ongoing follow up and advice.

\section{Considerations and recommendations for HSCT in neurologic autoimmune diseases}

Immune-mediated neurological disorders (IMNDs) affect the central and the peripheral nervous systems resulting in a range of diseases including MS, neuromyelitis optica spectrum disorder (NMOSD), stiff person spectrum disorder, myasthenia gravis, chronic inflammatory demyelinating polyradiculoneuropathy (CIDP), autoimmune encephalopathies, and others [27].

The limited available evidence suggests that IMNDs and their treatments affect the susceptibility to or the severity of
COVID-19. Patients with MS have increased risk of several types of infections compared to the general population particularly if they are on B-cell depleting therapies, such as rituximab $[28,29]$. An earlier study from Italy reported on 232 MS patients from 38 centers with confirmed or suspected COVID-19 [30], did not show any significant association between previous DMT exposure and COVID-19 severity. Of those patients, 223 had mild, 4 had severe, and 6 had critical infection.

In a registry-based study of 347 patients with MS, age, EDSS score, and obesity were found to be independent risk factors for severe COVID-19, although no association was found between DMTs exposure and COVID-19 severity [31]. Another study suggested that the incidence of COVID19 in MS patients was not more than that of the general 
Table 3 Summary of recommendations for autologous HSCT in RMDs in the time of COVID-19.

\begin{tabular}{|c|c|c|c|c|}
\hline & $\begin{array}{l}\text { Strength of evidence and } \\
\text { recommendations [21] }\end{array}$ & $\begin{array}{l}\text { Clinical } \\
\text { priority [22] }\end{array}$ & $\begin{array}{l}\text { Maximum } \\
\text { COVID-19 Alert } \\
\text { Level }[23,24]\end{array}$ & $\begin{array}{l}\text { Minimum setting } \\
\text { required [8] }\end{array}$ \\
\hline $\mathrm{SSc}$ & $\mathrm{S} / \mathrm{I}$ & $\begin{array}{l}1 \\
2\end{array}$ & $\begin{array}{l}4 \\
3\end{array}$ & $\begin{array}{l}\text { Prospective } \\
\text { studies } \\
\text { Registry }\end{array}$ \\
\hline SLE & $\mathrm{CO} / \mathrm{II}$ & $\begin{array}{l}1 \\
2\end{array}$ & $\begin{array}{l}3 \\
2\end{array}$ & Registry \\
\hline Vasculitis & $\mathrm{CO} / \mathrm{II}$ & $\begin{array}{l}1 \\
2\end{array}$ & $\begin{array}{l}3 \\
2\end{array}$ & Registry \\
\hline $\begin{array}{l}\text { Polymyositis- } \\
\text { dermatomyositis }\end{array}$ & $\mathrm{CO} / \mathrm{II}$ & $\begin{array}{l}1 \\
2\end{array}$ & $\begin{array}{l}3 \\
2\end{array}$ & Registry \\
\hline RA or JIA & $\mathrm{CO} / \mathrm{II}$ & $\begin{array}{l}1 \\
2\end{array}$ & $\begin{array}{l}3 \\
2\end{array}$ & Registry \\
\hline
\end{tabular}

Strength of evidence of clinical efficacy [21] — Grade I: evidence from at least one well-executed randomised trial, Grade II: evidence from at least one well-designed clinical trial without randomization; cohort or casecontrolled analytic studies, Grade III: evidence from opinions of respected authorities based on clinical experience. Recommendations [21]: $S$ standard of care, $C O$ clinical option, GNR generally not recommended.

Clinical priority (as determined by a relevant multidisciplinary team) [22] - (1) high, delaying the HSCT procedure presents a high risk of disease progression, morbidity, or mortality, (2) intermediate, there is risk of disease progression or clinical complications if HSCT is delayed significantly, (3) low, the risk of disease progression or clinical complications if HSCT is significantly delayed is low.

COVID-19 Alert Level [23, 24]—Level 1 (very low): COVID-19 is not known to be present; Level 2 (low): infection is present but the number of cases and transmission rate are low ( $R$ [26] below 1, growth rate [26] below 0 and average weekly number of new cases of $<20$ per 100000 population); Level 3 (moderate): infection is epidemic in the general population but transmission is not high or rising exponentially ( $\mathrm{R}$ [26] below 1, growth rate [26] below 0 and average weekly number of new cases of 20 or more per 100,000 population); Level 4 (high): infection is epidemic in the general population; transmission is high or rising exponentially ( $\mathrm{R}$ [26] above 1 and growth rate [26] above 0); Level 5 (very high): as Level 4 but with material risk of healthcare services being overwhelmed.

Setting-prospective studies: randomized controlled trials (RCTs) and other clinical trials, or prospective non-interventional studies (NIS). Registry: reporting data to EBMT registry (or equivalent international registry, e.g., CIBMTR).

HSCT autologous hematopoietic stem cell transplantation, RMDs rheumatic and musculoskeletal diseases, $S S c$ systemic sclerosis, $S L E$ systemic lupus erythematosus, $R A$ rheumatoid arthritis, JIA juvenile idiopathic arthritis, CIBMTR Center for International Blood and Marrow Transplant Research, N/A not applicable. population, but the risk of hospitalization in these patients was higher than estimated for the disease [32]. The prevalence and impact of COVID-19 across Europe were assessed in the 399 patients with MS taking part in the RADAR-CNS programme [33]; of those $21.8 \%$ reported major symptoms suggestive of COVID-19, mainly associated to alemtuzumab and cladribine treatments. In the MS Global Data Sharing Initiative [34], clinician-reported data from 21 countries on 1540 patients in which 776 (50.4\%) had confirmed COVID-19, and confirmed that older age, progressive MS, and higher EDSS scores were associated with higher frequencies of severe outcomes. Anti-CD20 DMTs, ocrelizumab, and rituximab were positively associated with hospital and ICU admission and the need for artificial ventilation compared to all other DMTs.

Therefore, patients with MS seem to be affected by the same risk factors as the general population, high EDSS scores appear to be an MS-specific risk factor and the majority of DMT treatment does not seem to be associated with a particularly poor prognosis.

Data related to other IMNDs are limited. CARE-MG registry reported worsening of myasthenic control requiring rescue therapy in the setting of COVID-19 in 36 of 91 patients. Complete recovery or discharge to home was reported in $39(43 \%)$ patients whereas 22 (24\%) patients died due to COVID-19 [35]. The clinical course and outcome of patients with COVID-19 and NMOSD seem to be variable [36-38] and also exacerbations of CIDP have been reported [39].

The use of autologous HSCT in the treatment of IMNDs is expanding and becoming increasingly evidence-based [7, 40-42]. Recently, the first phase III randomized controlled trial [41] in MS has demonstrated its efficacy in patients with active relapsing remitting disease failing standard DMTs. A number of phase II non-randomized trials have also shown its safety and efficacy in treatment- 


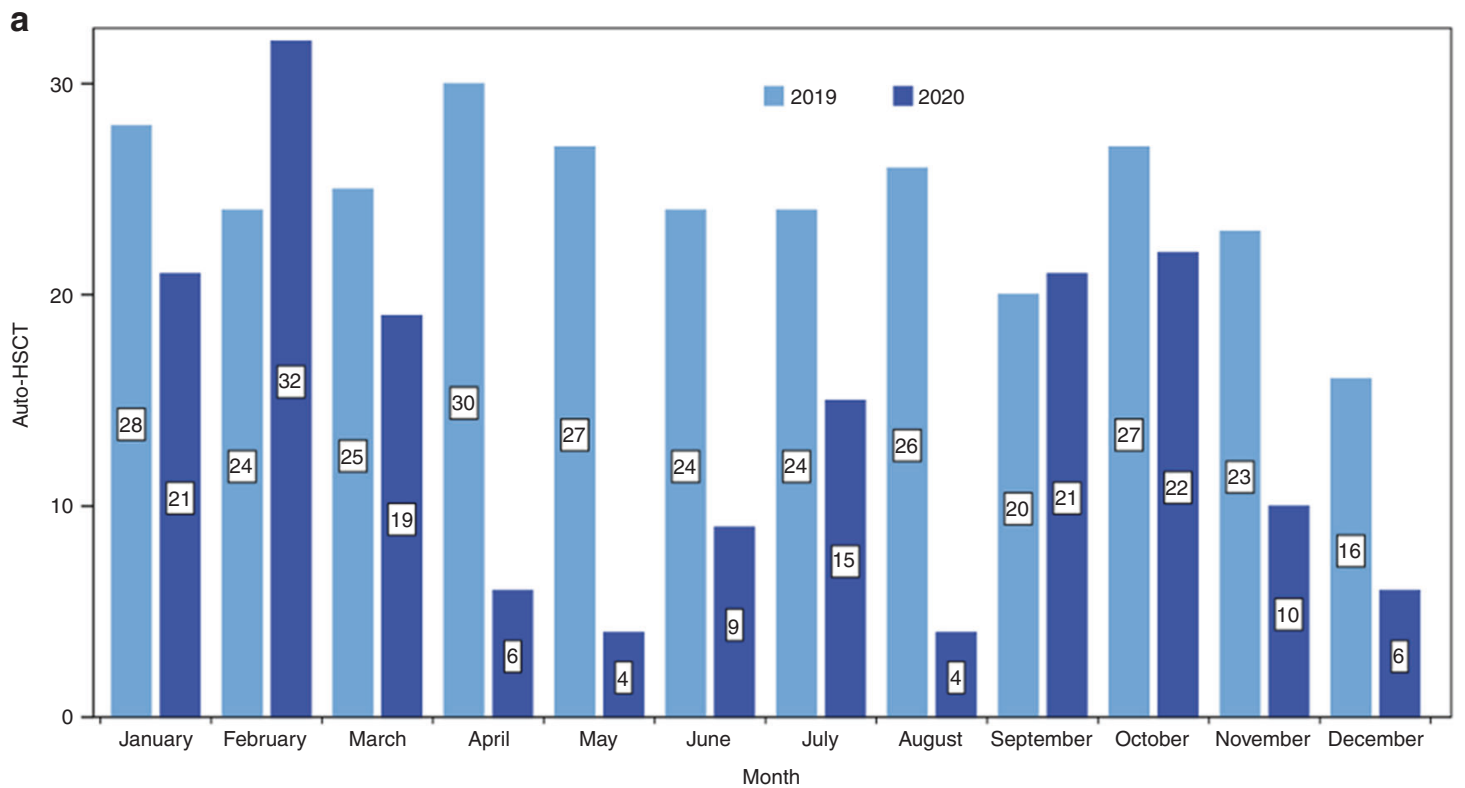

b
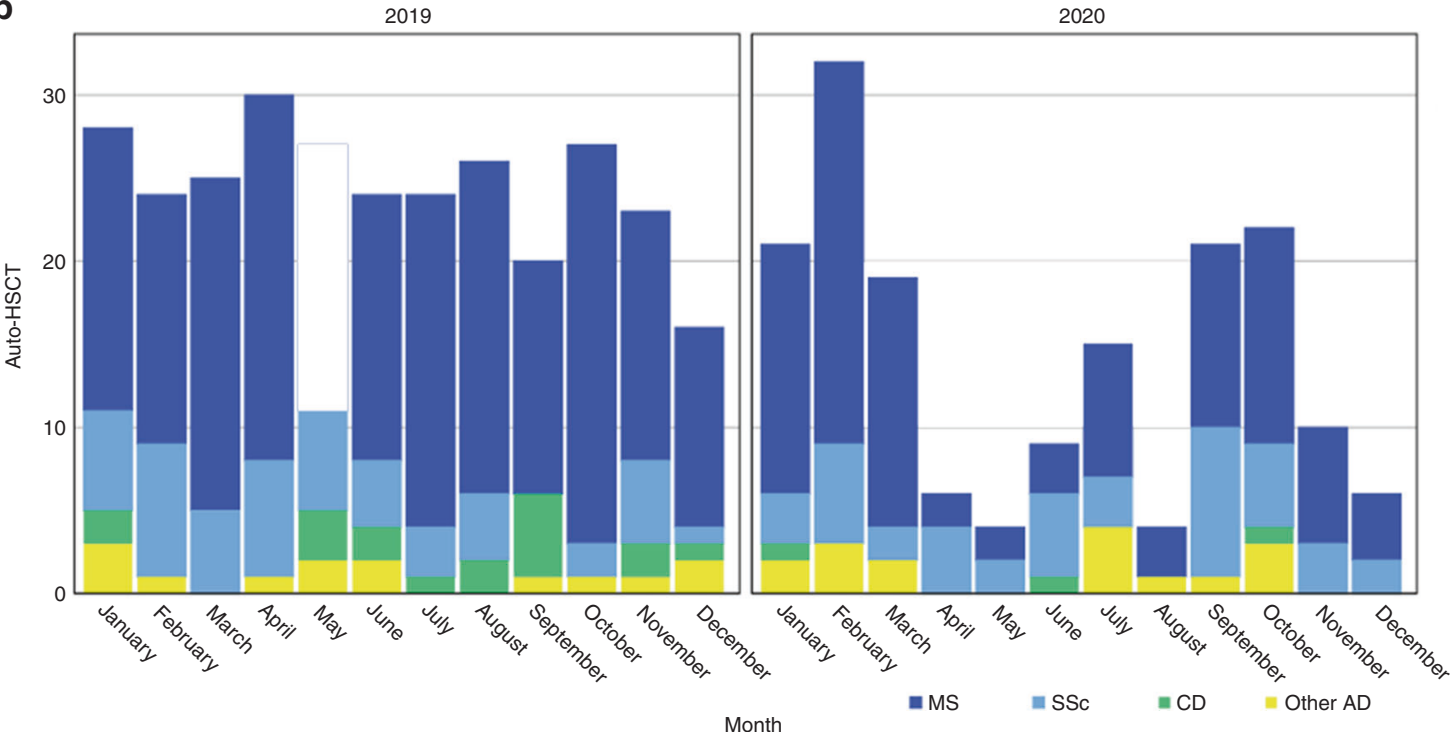

Fig. 1 Autologous hematopoietic stem cell transplant (HSCT) for autoimmune diseases (ADs) 2019-2020, reflecting the impact of the COVID-19 pandemic in Europe. a Numbers of autologous HSCT in January to December 2020 are compared with the numbers in January to December 2019; b 2019-2020 transplants are also represented according to disease indication (MS: deep blue; SSc: light blue; CD: green; other ADs: yellow). auto-HSCT autologous hematopoietic stem cell transplantation, AD autoimmune disease, MS multiple sclerosis, SSc systemic sclerosis, CD Crohn's disease.

case, with any type of regimen, a patient would be considered at high risk in case of SARS-CoV-2 infection $[39,47,48]$.

The most appropriate choice of conditioning regimen should be addressed for each individual patient, after a careful assessment of diagnosis, disease stage, and overall clinical condition at baseline. Therefore the use of this treatment should be restricted to patients with a clear risk/ benefit ratio based on treatment-resistant disease entity, according to the level of evidence for autologous HSCT 
efficacy in this particular disease, defined clinical priorities [22], and local COVID-19 Alert Levels (Table 2) [23].

All treatment-related decisions should be made by MDTs and patients should be treated within clinical trials if available or as part of well-defined registry studies to allow longitudinal collection of efficacy and safety data of the various treatment options. Patients with severe comorbidities known to be associated with poor COVID-19 outcomes should not be considered for HSCT during the pandemic.

\section{Considerations and recommendations for HSCT in rheumatic diseases}

The COVID-19 pandemic has considerable impact on different aspects of the management of patients with rheumatic and musculoskeletal diseases (RMDs). Chronic suppression of immune functions, both with synthetic or biologic DMTs, is the cornerstone of treatment in those indications [49-53]. Alongside, autologous HSCT has emerged as an established treatment option for some indications where effective drug therapy is not available, even in the biological era. Particularly, three randomized controlled trials (ASSIST, ASTIS and SCOT) have demonstrated the superiority of HSCT compared to monthly IV bolus of cyclophosphamide in patients with early rapidly progressive SSc in terms of event-free and overall survival, improvement of skin fibrosis, and evidence for benefits on pulmonary function [54-56]. SSc is now considered a standard indication for autologous HSCT [21, 57]. Other diseases in which the use of HSCT is supported by evidence from nonrandomized controlled trials and is regarded as treatment option include systemic lupus erythematosus (SLE), vasculitides, polymyositis/dermatomyositis, and both rheumatoid and juvenile idiopathic arthritis [21].

Chronic use of DMTs may be associated with an increased risk of infection-related morbidity and mortality in RMDs [58, 59]. However, despite this notion, accumulating data from larger case series, national and international registries suggest that patients with RMDs neither have an increased risk of developing SARS-CoV-2 infection nor do they have a worse prognosis compared to the general population [60-63]. Only RMD patients on high-dose corticosteroids, but not methotrexate and biologic DMTs, nonsteroidal anti-inflammatory drugs and antimalarial drugs had a higher risk of SARS-CoV-2 infection or hospitalization [60-62, 64, 65]. However, recent data from the French RMD COVID-19 cohort including 694 adults indicated for the first time an increased risk for severe infection in patients receiving mycophenolate mofetil or rituximab [65]. Conversely, RMD patients on a background tumor necrosis factor (TNF) inhibitor had an adjusted $60 \%$ reduction in risk of hospitalization [62], and recently the FDA authorized the emergency use of baricitinib in certain hospitalized patients with COVID-19. Overall, risk factors for more severe COVID-19 in RMD patients include older age and comorbid conditions [65]. The only rheumatic disease diagnosis with odds of hospitalization significantly different from other RMDs seems to be SLE. Data from the Global Rheumatology Alliance (GRA) Registry indicated that lupus patients were at $80 \%$ increased risk of hospitalization [62]. Patients with SSc are largely underrepresented in international COVID-19 registries and their risk during COVID-19 pandemic is evaluated incompletely. Nevertheless, first single-center studies and personal observations indicated that incidence of confirmed SARS-CoV-2 infections was low and severe complications, including death, were rare. Only one death and 11 infections related to COVID-19 have been reported among 526 Italian SSc patients [66]. Overall, 390 (10.5\%) died out of 3729 RMD patients included in the GRA physician COVID-19 registry [67]. Provisional recommendations for the management of RMD patients were published based on expert consensus from international task forces of the EULAR [68] and ACR [69]. Both recommendations strongly suggest continuing the DMTs treatment in RMD patients who do not have suspected or confirmed COVID-19. In addition, management of RMD patients following SARS-CoV-2 exposure and documented infection, and the use of immunosuppressive drugs, should be multidisciplinary, discouraging the off-label use of DMTs outside the context of clinical trials [68].

The use of HSCT in RMDs must be carefully weighed against the risk of the procedure, should be based on the strengths of evidence per indication and ideally performed as part of a clinical study. Particularly, access to intensive care medicine and resources for appropriate screening procedures, including the recommended cardiopulmonary screening assessments for SSc patients should be available [63]. Appropriate candidates for autologous HSCT during COVID-19 pandemic should therefore be those with high clinical priority, reflected by life-threatening and otherwise refractory courses of the disease, i.e., unresponsiveness or lack of tolerability to standard or alternative DMTs therapies, in which delaying the HSCT procedure may be associated with a high risk of disease progression, morbidity, or mortality (Table 3).

In summary, continuation with autologous HSCT for RMD patients during COVID-19 pandemic can be recommended, presupposing a risk adjustment according to local SARS-CoV-2 infection rates and medical resources, strengths of evidence of HSCT per indication, lack of alternative therapies and adoption of a prioritization process, delivering HSCT based on clinical urgency. 


\section{Considerations and recommendations for gastrointestinal diseases}

In gastroenterology, the main area application of autologous HSCT has been in inflammatory bowel diseases (IBDs), particularly Crohn's disease (CD) [9, 10]. Although the COVID-19 pandemic has led to substantial concerns for patients with IBDs, as a high proportion of them receive immunosuppressive therapies [70], similar COVID-19 rates and no increased mortality have been reported as compared to the general population [71-73]. Corticosteroids may pose significant risk to IBD patients with COVID-19 [72]. In addition, recent results demonstrated that thiopurine treatment, either as monotherapy or in combination with TNF inhibitors, was associated with increased risk of severe COVID-19 [74, 75]. Anti-TNF therapy, anti-integrins, and anti-IL12/23 have not been associated with increased mortality $[71,73]$.

Recommendations in the management of IBD suggest that medical treatments should be re-evaluated in SARSCoV-2-positive patients and corticosteroid therapy should be re-evaluated regardless of symptoms. A goal should be to treat active disease and maintain remission, while adopting the same protective measures as the general population. In addition, nonurgent surgeries and endoscopic procedures should be postponed [76]. The use of autologous HSCT should be restricted to patients with a clear risk/ benefit ratio, according to strengths of evidence of HSCT per indication, clinical priorities [22], and local COVID-19 Alert Levels (Table 4) [23].

\section{Considerations and recommendations for pediatric population}

Only limited data are available on risks of HSCTs in pediatric ADs [76, 77] during the COVID-19 outbreak [30]. There was no significant association between previous DMTs and COVID-19 severity in children [77]. Therefore, children post-HSCT for ADs usually have a story of intensive immunosuppression and are at potential risk during the COVID-19 outbreak [13]. A rapid global response for children with cancer was published [78]. Feasibility of HSCT for pediatric ADs during the COVID-19 outbreak was demonstrated, provided there is the availability of hospital resources. Therefore, during the pandemic outbreak, the indication for HSCT in children with ADs must be restricted to patients with a clear risk/benefit ratio [78]. In children, it could be severe "malignant" forms of neurological ADs, severe progressive systemic diseases, $\mathrm{CD}$, and immune cytopenias.

Considering the better outcomes of HSCT in children during the COVID-19 outbreak, a less restrictive approach could be applied [79]. As patients with pediatric ADs are mostly transplanted in the same departments as patients with malignancies, priority must be given to these children followed by patients with severe ADs [78]. Centers must be very careful using immunotherapy such as ATG as well as monoclonal antibodies [80]. Preferably, only one parent or guardian, identified as the primary caregiver, and with a recent negative swab for SARS-CoV-2, may be present in the room with a pediatric patient, requesting a visitor exception to the local care team.

\section{Special recommendations for vaccinations}

The response to the pandemic includes efforts to develop safe and effective vaccines [81] with an unprecedented urgency and large-scale investment of human and financial resources [82].

All the main arms of the immune response are involved in the generation of protective immunity to SARS-CoV-2: innate immune responses as well as adaptive immunity, including humoral and T-cell responses. SARS-CoV-2 has the ability to suppress innate immune responses [81]. Antibody responses to the Coronavirus spike (S) protein develop during COVID-19 infection in the majority of subjects [83]. Emerging evidence indicates that T-cell mediated immunity may be critically important against COVID-19 [81, 84, 85]. Collectively, these data suggest that individuals with compromised innate or adaptive immunity may not only be at risk of more severe COVID19 disease but also at higher risk of lacking protective immunity from infection or vaccination.

The guidelines of the 2017 European Conference on Infections in Leukaemia provide general recommendations for vaccination in HSCT recipients [86]. Recently, EBMT has provided specific COVID-19 vaccine recommendations [20]. The vaccines against COVID-19 currently approved for use in EU, following review by EMA, can be grouped in two platforms: recombinant replication-defective viral-vectored vaccines and mRNA-based vaccines [20, 81]. No evidence is published to inform us on the safety and efficacy of any COVID-19 vaccine in HSCT recipients. Based on inferences from other current evidence [20, 87, 88], we suggest that live-attenuated COVID-19 vaccines or vectored by live-attenuated viruses should be contraindicated in HSCT recipients. For all other COVID-19 vaccine types, we suggest that vaccination could be considered from 3 months after HSCT. Follow-up after vaccination is therefore important. Continued precautions should be taken based on the pandemic situation in the society [20, 89]. Individuals vaccinated before HSCT will almost certainly lose protective immunity after HSCT and may require revaccination. Clinical trials in HSCT patients are needed to establish the safety and immune response of vaccines against COVID-19. 
Table 4 Summary of recommendations for autologous HSCT in IBDs in the time of COVID-19.

\begin{tabular}{lllll}
\hline & $\begin{array}{l}\text { Strength of evidence and } \\
\text { recommendations [21] }\end{array}$ & $\begin{array}{l}\text { Clinical } \\
\text { priority [22] }\end{array}$ & $\begin{array}{l}\text { Maximum COVID-19 } \\
\text { Alert level [23, 24] }\end{array}$ & $\begin{array}{l}\text { Minimum setting } \\
\text { required [8] }\end{array}$ \\
\hline Crohn's & CO/II & 1 & 3 & Registry \\
disease & & 2 & 2 & \multirow{2}{*}{ Registry } \\
RCD II & CO/II & 1 & 3 & \\
& & 2 & 2 & \\
\hline
\end{tabular}

Strength of evidence of clinical efficacy [21]—Grade I: evidence from at least one well-executed randomised trial, Grade II: evidence from at least one well-designed clinical trial without randomization; cohort or casecontrolled analytic studies, Grade III: evidence from opinions of respected authorities based on clinical experience. Recommendations [21]: $S$ standard of care, $C O$ Clinical option, GNR generally not recommended.

Clinical priority (as determined by a relevant multidisciplinary team) [22] - (1) high, delaying the HSCT procedure presents a high risk of disease progression, morbidity or mortality, (2) intermediate, there is risk of disease progression or clinical complications if HSCT is delayed significantly, (3) low, the risk of disease progression or clinical complications if HSCT is significantly delayed is low.

COVID-19 Alert Level [23, 24]—Level 1 (very low): COVID-19 is not known to be present; Level 2 (low): infection is present but the number of cases and transmission rate are low ( $\mathrm{R}$ [26] below 1, growth rate [26] below 0 and average weekly number of new cases of $<20$ per 100,000 population); Level 3 (moderate): infection is epidemic in the general population but transmission is not high or rising exponentially ( $\mathrm{R}$ [26] below 1, growth rate [26] below 0 and average weekly number of new cases of 20 or more per 100,000 population); Level 4 (high): infection is epidemic in the general population; transmission is high or rising exponentially (R [26] above 1 and growth rate [26] above 0); Level 5 (very high): as Level 4 but with material risk of healthcare services being overwhelmed.

Setting-prospective studies: randomized controlled trials (RCTs) and other clinical trials, or prospective non-interventional studies (NIS). Registry: reporting data to EBMT registry (or equivalent international registry, e.g., CIBMTR).

$H S C T$ autologous hematopoietic stem cell transplantation, $I B D$ inflammatory bowel diseases, $R C D$ refractory celiac disease, CIBMTR Center for International Blood and Marrow Transplant Research, N/A not applicable.

\section{Data reporting}

Routine data reporting should continue into the EBMT registry, and, alongside, we strongly encourage center participation in the ongoing EBMT-wide prospective survey on the impact of COVID-19 in HSCT recipients [19].

\section{Clinical trials}

With respect to clinical trials, special consideration should be made by trial management groups, oversight committees, sponsors, and local principal investigators in the best interests of patients in relation to the trial protocol and recruitment during the pandemic [90]. Even so, clinical trials provide a means of actively monitoring the impact of the COVID-19 pandemic on outcomes.

\section{Quality and accreditation}

In EBMT, quality in HSCT and cellular therapy is assured through JACIE accreditation, which has been central to EBMT recommendations for HSCT in ADs [8]. Elsewhere, equivalent quality assurance is provided by FACT, based on harmonized FACT_JACIE standards. Therefore, we recommend that HSCT procedure should only be carried out in experienced centers with an active accreditation by JACIE or FACT [7].

As the situation may change over time, the current statements should be reviewed at regular intervals and read in conjunction with general EBMT guidelines [20] on the COVID-19 pandemic, which are continually updated [20], along with local and national guidance.

\section{Conclusions}

Although current evidence suggests that HSCT is a valid treatment option in the management of selected patients with ADs, its intense immunosuppression could expose to increased risks during the current COVID-19 pandemic [13, 47, 48]. Therefore the use of autologous HSCT during the pandemic should be restricted to AD patients with a clear risk/benefit ratio based on disease entity, level of evidence for HSCT efficacy in this setting, defined clinical priorities [22], and local COVID-19 Alert Levels (Tables 2-4) [23]. All patients being considered for HSCT should be discussed in appropriately constituted MDT meetings (including transplant and disease specialists) with individual assessment of risks and benefits of HSCT as best as possible and considering the current and predicted 
geographical variations in the pandemic related to transplant center, referral center, and home locality of the patient (which may be different). HSCT programs must be ready to rapidly adapt to change following the course of the pandemic. Updates of this COVID-19-specific guidance will be incorporated within updates to recommendations from EBMT for specific ADs.

Acknowledgements The authors contribute this article on behalf of Autoimmune Diseases Working Party (ADWP) of the European Society for Blood and Marrow Transplantation (EBMT) and the Joint Accreditation Committee of ISCT (JACIE). We acknowledge the ADWP for support in working party activities and outputs; Infectious Diseases Working Party (IDWP) and Pediatric Working Party (PWP); and all EBMT member centers and their clinicians, data managers, and patients for their essential contributions to the EBMT registry. The EBMT Autoimmune Diseases Working Party (ADWP) included: Raffaella Greco (Chair), Tobias Alexander (Secretary), John Snowden (Chair April 2016 to May 2020), Manuela Badoglio (Study Coordinator), Myriam Labopin (Statistician) and actively participating clinicians; Mario Abinun, Shashikant Apte, Renate Arnold, Claudia Boglione (EBMT Nurses Group representative), Charlotte Brierley, Joachim Burman, Cristina Castilla-Llorente, Nichola Cooper, Giulia Daghia, Thomas Daikeler, Nicoletta del Papa, Jeska de VriesBouwstra, Dominique Farge, Jurgen Finke, Hans Hagglund, Chris Hawkey, Jörg Henes, Falk Hiepe, Helen Jessop (EBMT Nurses Group representative), David Kiely, Majid Kazmi, Kirill Kirgizov, Ellen Kramer (also representing the EBMT Patient Advocacy Committee), Gianluigi Mancardi, Zora Marjanovic, Roland Martin, Thierry Martin, David Ma, John Moore, Paul Miller, Paolo Muraro, Maria-Carolina Oliveira, Alexey Polushin, Francesco Onida, Belinda Simoes, Mathieu Puyade, Igor Resnick, Elena Ricart, Montserrat Rovira, Riccardo Saccardi, Muhammad Saif, Ioanna Sakellari, Basil Sharrack, Emilian Snarski, Hans Ulrich Scherer, Claudia Sossa, Barbara Withers, Nico Wulffraat, Eleanora Zaccara. The EBMT JACIE Committee included: Kim Orchard (Chair), John Snowden, Riccardo Saccardi, Franco Bambi, Fermín Sanchez- Guijo, Nina Worel. The EBMT Paediatric Diseases Working Party included: Persis Amrolia, Marc Ansari, Adriana Balduzzi, Selim Corbacioglu (Chair), Arnaud Dalassier, JeanHugues Dalle, Cristina Hereda Diaz, Tobias Feuchtinger, Franco Locatelli, Giovanna Lucchini, Jaques-Emmanuel Galimard, Marta Gonzalez Vincent, Rupert Handgretinger, Katharina Kleinschmidt (Secretary), Anita Lawitschka, Antonio Perez Martinez, Christina Peters, Vanderson Rocha, Annalisa Ruggeri, Petr Sedlacek, Peter Svec, Jacek Toporski, and Akif Yesilipek. The EBMT Infectious Diseases Working Party (IDWP) included: Iris Agreiter, Mahmoud Aljurf, Ana Sofia Almeida, Dina Averbuch (Secretary), Sherif Badawy, Gregorz Basak, Amer Beitinjaneh, Haydee Bernhard, Roni Bitterman, Ola Blennow, Nicole Blijlevens, Alessandro Busca, Jun Cai, Mansour Ceesay, Simone Cesaro, Benhur Cetin, Teresa Daniela Clerici, Patrizia Comoli, Catherine Cordonnier, Consoelo Corti, Elizabeth de Kont, Rafael de la Camara (Chair), Joanna DrozdSokowska, Jaroslaw Dybko, Hermann Einsele, Dan Engelaard, Ildefonso Espigado, Jose-Maria Fernandez-Navarro, Irene Garcia-cadenas, Lidia Gil, Marta Gonzalez Vincent, Andreas Groll, Hans Hirsch, Stefan Klein, William Kruger, Lalit Kumar, Arjan Lankster, Amandine Le Boungeois, Caroline Lindemans, Per Ljungman, Jose Luis Lopez, Maria Teresa Lupo Stanghellini, Nuria Martinez-Cibrian, Rodrigo Martino, Michael Mclinger, Varun Mehra, Patrycja Mensah-Glanowska, Malgorzata Mikulska, Ilana Oren, Amit Patel, Mehrdad Payandeh, Katia Perruccio, Anna Pieczonka, Agnieszka Piekarska, Jose Luis Pinana, Miguel Perales, Regina Pirumova, Christine Robin, Montserrat Rovira, Martin Schmidt-Hieber, Laura Scott, Liat Shargian, Peter Shaw, Emilian Snarski, Maria Stamouli, Jan Styczinski, Maria
Suarez-Lledo, Daniel Teschner, Gloria Tridello, Gauran Trikha, Rosario Varela, Lourdes Vazquez, Anke Verlinden, Sebastian Voigt, Jacek Wachowiak, Kate Ward, Alienor Xhaard, Nabil Yafour.

Author contributions The authorship group includes active representatives of the ADWP, IDWP, PWP, and JACIE, including representatives from the EBMT. Nurses Group and Patient Advocacy Committee. RG, JAS, and TA led on concept, design, coordination, and data analysis, provided expert and analytical feedback and were involved in reviewing, writing, and editing the manuscript. All authors contributed to the acquisition, analysis of data and interpretation of information, writing sections of the manuscript. BS led the section on immune-mediated neurological diseases and devised the risk-level assessment. PAM made substantial contributions to aspects on immune reconstitution and vaccinations. The experts on this panel are active members of the EBMT and national links for the main countries contributing to the registry. All co-authors were involved in drafting the paper, revising it critically, and approval of the submitted and final versions. The EBMT provided resources via the working parties, data office, and registry. Other than EBMT support there is no funding body supporting these guidelines, commercial, or otherwise.

\section{Compliance with ethical standards}

Conflict of interest RG discloses honoraria for speaking from educational events supported by Biotest, Pfizer, and Magenta. JAS declares honoraria for speaking at educational events supported by Jazz, Gilead, Janssen, Mallinckrodt, Actelion, an advisory board by MEDAC, and is a member of IDMC for a trial supported by Kiadis Pharma. TA declares travel grants from Neovii and study support from Amgen. PAM discloses travel support and speaker honoraria from unrestricted educational activities organized by Novartis, Bayer HealthCare, Bayer Pharma, Biogen Idec, Merck-Serono, and Sanofi Aventis. He also discloses consulting to Magenta Therapeutics and Jasper Therapeutics. PL reports grants and other from MSD, outside the submitted work. The other authors declare no competing interests.

Ethics approval This review, guideline and recommendations, and registry data analysis were approved, led, and supported by the Autoimmune Diseases Working Party (ADWP) and have been endorsed by the Pediatric (PWP) and Infectious Disease Working Parties (IDWP), Nurses Group (NG) of the European Society for Blood and Marrow Transplantation (EBMT), and the Joint Accreditation Committee of the International Society for Cellular Therapy (ISCT) and EBMT (JACIE).

Publisher's note Springer Nature remains neutral with regard to jurisdictional claims in published maps and institutional affiliations.

Open Access This article is licensed under a Creative Commons Attribution 4.0 International License, which permits use, sharing, adaptation, distribution and reproduction in any medium or format, as long as you give appropriate credit to the original author(s) and the source, provide a link to the Creative Commons license, and indicate if changes were made. The images or other third party material in this article are included in the article's Creative Commons license, unless indicated otherwise in a credit line to the material. If material is not included in the article's Creative Commons license and your intended use is not permitted by statutory regulation or exceeds the permitted use, you will need to obtain permission directly from the copyright holder. To view a copy of this license, visit http://creativecommons. org/licenses/by/4.0/. 


\section{References}

1. Wiersinga WJ, Rhodes A, Cheng AC, Peacock SJ, Prescott HC. Pathophysiology, transmission, diagnosis, and treatment of Coronavirus Disease 2019 (COVID-19): a review. JAMA. 2020;324: 782-93. https://doi.org/10.1001/jama.2020.12839.

2. Gandhi RT, Lynch JB, Del Rio C. Mild or moderate Covid-19. N Engl J Med. 2020;383:1757-66. https://doi.org/10.1056/ NEJMcp2009249.

3. Berlin DA, Gulick RM, Martinez FJ. Severe Covid-19. N Engl J Med. 2020;383:2451-60. https://doi.org/10.1056/NEJMcp2009575.

4. Chen G, Wu D, Guo W, Cao Y, Huang D, Wang H, et al. Clinical and immunological features of severe and moderate coronavirus disease 2019. J Clin Invest. 2020;130:2620-9. https://doi.org/10.1172/JCI137244.

5. Ciceri F, Castagna A, Rovere-Querini P, De Cobelli F, Ruggeri A, Galli L, et al. Early predictors of clinical outcomes of COVID-19 outbreak in Milan, Italy. Clin Immunol. 2020;217:108509. https://doi.org/10.1016/j.clim.2020.108509.

6. Jacques FH, Apedaile E. Immunopathogenesis of COVID-19: summary and possible interventions. Front Immunol. 2020;11:564925. https://doi.org/10.3389/fimmu.2020.564925.

7. Sharrack B, Saccardi R, Alexander T, Badoglio M, Burman J, Farge D, et al. Autologous haematopoietic stem cell transplantation and other cellular therapy in multiple sclerosis and immune-mediated neurological diseases: updated guidelines and recommendations from the EBMT Autoimmune Diseases Working Party (ADWP) and the Joint Accreditation Committee of EBMT and ISCT (JACIE). Bone Marrow Transpl. 2020;55:283-306. https://doi.org/10.1038/s41409-019-0684-0.

8. Snowden JA, Badoglio M, Labopin M, Giebel S, McGrath E, Marjanovic Z, et al. Evolution, trends, outcomes, and economics of hematopoietic stem cell transplantation in severe autoimmune diseases. Blood Adv. 2017;1:2742-55. https://doi.org/10.1182/ bloodadvances.2017010041.

9. Snowden JA, Panes J, Alexander T, Allez M, Ardizzone S, Dierickx D, et al. Autologous haematopoietic stem cell transplantation (AHSCT) in Severe Crohn's Disease: a review on behalf of ECCO and EBMT. J Crohns Colitis. 2018;12:476-88. https://doi.org/10.1093/ecco-jcc/jjx184.

10. Alexander T, Greco R, Snowden JA. Hematopoietic stem cell transplantation for autoimmune disease. Annu Rev Med. 2021;72:215-28. https://doi.org/10.1146/annurev-med-070119115617.

11. Fung M, Babik JM. COVID-19 in immunocompromised hosts: what we know so far. Clin Infect Dis. 2021;72:340-50. https:// doi.org/10.1093/cid/ciaa863.

12. Pinana JL, Martino R, Garcia-Garcia I, Parody R, Morales MD, Benzo G, et al. Risk factors and outcome of COVID-19 in patients with hematological malignancies. Exp Hematol Oncol. 2020;9:21. https://doi.org/10.1186/s40164-020-00177-z.

13. Minotti C, Tirelli F, Barbieri E, Giaquinto C, Dona D. How is immunosuppressive status affecting children and adults in SARS-CoV-2 infection? A systematic review. J Infect. 2020;81: e61-6. https://doi.org/10.1016/j.jinf.2020.04.026.

14. Vijenthira A, Gong IY, Fox TA, Booth S, Cook G, Fattizzo B, et al. Outcomes of patients with hematologic malignancies and COVID-19: a systematic review and meta-analysis of 3377 patients. Blood. 2020;136:2881-92. https://doi.org/10.1182/ blood.2020008824.

15. Chari A, Samur MK, Martinez-Lopez J, Cook G, Biran N, Yong KL, et al. Clinical features associated with COVID-19 outcome in MM: first results from International Myeloma Society Dataset. Blood. 2020;136:3033-40. https://doi.org/10.1182/blood.2020008150.
16. He W, Chen L, Chen L, Yuan G, Fang Y, Chen W, et al. COVID-19 in persons with haematological cancers. Leukemia. 2020;34:1637-45. https://doi.org/10.1038/s41375-020-0836-7.

17. Wood WA, Neuberg DS, Thompson JC, Tallman MS, Sekeres MA, Sehn LH, et al. Outcomes of patients with hematologic malignancies and COVID-19: a report from the ASH Research Collaborative Data Hub. Blood Adv. 2020;4:5966-75. https:// doi.org/10.1182/bloodadvances.2020003170.

18. Schoot TS, Kerckhoffs APM, Hilbrands LB, van Marum RJ. Immunosuppressive drugs and COVID-19: a review. Front Pharm. 2020;11:1333. https://doi.org/10.3389/fphar.2020.01333.

19. Ljungman P, Mikulska M, de la Camara R, Basak GW, Chabannon C, Corbacioglu S, et al. The challenge of COVID-19 and hematopoietic cell transplantation; EBMT recommendations for management of hematopoietic cell transplant recipients, their donors, and patients undergoing CAR T-cell therapy. Bone Marrow Transpl. 2020;55:2071-6. https://doi.org/10.1038/ s41409-020-0919-0.

20. EBMT. EBMT guidelines. https://www.ebmt.org/covid-19-andbmt.

21. Duarte RF, Labopin M, Bader P, Basak GW, Bonini C, Chabannon $\mathrm{C}$, et al. Indications for haematopoietic stem cell transplantation for haematological diseases, solid tumours and immune disorders: current practice in Europe, 2019. Bone Marrow Transpl. 2019;54:1525-52. https://doi.org/10.1038/ s41409-019-0516-2.

22. National Institute for Health and Care Excellence Ng. COVID-19 rapid guideline: haematopoietic stem cell transplantation. 2020. https://www.nice.org.uk/guidance/ng164.

23. HM Government. COVID Alert Levels. https://assets.publishing. service.gov.uk/government/uploads/system/uploads/attachment_ data/file/884352/slides_-_11_05_2020.pdf.

24. Stevens RHR, Perera R, Jason Oke J. Should COVID-19 travel quarantine policy be based on apparent new case rates? The Centre for Evidence-Based Medicine. https://www.cebm.net/ 2020/09/should-covid-19-travel-quarantine-policy-be-based-on-a pparent-new-case-rates/.

25. NICE guideline. COVID-19 rapid guideline: arranging planned care in hospitals and diagnostic services. 2020. https://www.nice. org.uk/guidance/ng179.

26. https://royalsociety.org/-/media/policy/projects/set-c/set-covid19-R-estimates.pdf.

27. Das J, Sharrack B, Snowden JA. Autologous hematopoietic stem-cell transplantation in neurological disorders: current approach and future directions. Expert Rev Neurother. 2020;20:1299-313. https://doi.org/10.1080/14737175.2020. 1820325.

28. Marrie RA, Elliott L, Marriott J, Cossoy M, Blanchard J, Tennakoon A, et al. Dramatically changing rates and reasons for hospitalization in multiple sclerosis. Neurology. 2014;83:929-937. https://doi.org/10. 1212/WNL.0000000000000753.

29. Luna G, Alping P, Burman J, Fink K, Fogdell-Hahn A, Gunnarsson $M$, et al. Infection risks among patients with multiple sclerosis treated with fingolimod, natalizumab, rituximab, and injectable therapies. JAMA Neurol. 2020;77:184-91. https://doi. org/10.1001/jamaneurol.2019.3365.

30. Sormani MP, Italian Study Group on C-iims. An Italian programme for COVID-19 infection in multiple sclerosis. Lancet Neurol. 2020;19:481-2. https://doi.org/10.1016/S1474-4422(20) 30147-2.

31. Louapre C, Collongues N, Stankoff B, Giannesini C, Papeix C, Bensa $\mathrm{C}$, et al. Clinical characteristics and outcomes in patients with Coronavirus Disease 2019 and multiple sclerosis. JAMA Neurol. 2020;77:1079-88. https://doi.org/10.1001/jamaneurol. 2020.2581 . 
32. Sahraian MA, Azimi A, Navardi S, Ala S, Naser Moghadasi A. Evaluation of the rate of COVID-19 infection, hospitalization and death among Iranian patients with multiple sclerosis. Mult Scler Relat Disord. 2020;46:102472. https://doi.org/10.1016/j. msard.2020.102472.

33. Dalla Costa G, Leocani L, Montalban X, Guerrero AI, Sorensen PS, Magyari M, et al. Real-time assessment of COVID-19 prevalence among multiple sclerosis patients: a multicenter European study. Neurol Sci. 2020;41:1647-50. https://doi.org/10. 1007/s10072-020-04519-x.

34. https://msvirtual2020.org/wp-content/uploads/2020/09/SS02.04. pdf. 2020.

35. Muppidi S, Guptill JT, Jacob S, Li Y, Farrugia ME, Guidon AC, et al. COVID-19-associated risks and effects in myasthenia gravis (CARE-MG). Lancet Neurol. 2020;19:970-1. https://doi. org/10.1016/S1474-4422(20)30413-0.

36. Mantero V, Rigamonti A, Basilico P, Crespi M, Balgera R, Salmaggi A. Mild COVID-19 infection in an NMO patient treated with tocilizumab: a confirmation of anti-IL-6 protective role? J Neurol. 2020;267:3465-6. https://doi.org/10.1007/ s00415-020-10039-7.

37. Anand P, Slama MCC, Kaku M, Ong C, Cervantes-Arslanian AM, Zhou L, et al. COVID-19 in patients with myasthenia gravis. Muscle Nerve. 2020;62:254-8. https://doi.org/10.1002/ mus.26918.

38. Mantero V, Rigamonti A, Basilico P, Crespi M, Balgera R, Salmaggi A. Mild COVID-19 infection in an NMO patient treated with tocilizumab: a confirmation of anti-IL-6 protective role? J Neurol. 2020. https://doi.org/10.1007/s00415-020-10039-7.

39. Abu-Rumeileh S, Garibashvili T, Ruf W, Fangerau T, Kassubek $\mathrm{J}$, Althaus $\mathrm{K}$, et al. Exacerbation of chronic inflammatory demyelinating polyneuropathy in concomitance with COVID-19. J Neurol Sci. 2020;418:117106. https://doi.org/10.1016/j.jns. 2020.117106

40. Muraro PA, Martin R, Mancardi GL, Nicholas R, Sormani MP, Saccardi R. Autologous haematopoietic stem cell transplantation for treatment of multiple sclerosis. Nat Rev Neurol. 2017;13:391-405. https://doi.org/10.1038/nrneurol.2017.81.

41. Burt RK, Balabanov R, Burman J, Sharrack B, Snowden JA, Oliveira MC, et al. Effect of nonmyeloablative hematopoietic stem cell transplantation vs continued disease-modifying therapy on disease progression in patients with relapsing-remitting multiple sclerosis: a Randomized Clinical Trial. JAMA. 2019;321:165-74. https://doi.org/10.1001/jama.2018.18743.

42. Atkins HL, Bowman M, Allan D, Anstee G, Arnold DL, Bar-Or A, et al. Immunoablation and autologous haemopoietic stem-cell transplantation for aggressive multiple sclerosis: a multicentre single-group phase 2 trial. Lancet. 2016;388:576-85. https://doi. org/10.1016/S0140-6736(16)30169-6.

43. Burt RK, Balabanov R, Tavee J, Han X, Sufit R, Ajroud-Driss S, et al. Hematopoietic stem cell transplantation for chronic inflammatory demyelinating polyradiculoneuropathy. J Neurol. 2020;267:3378-91. https://doi.org/10.1007/s00415-020-10010-6.

44. Burt RKBR, Han X, et al. Autologous hematopoietic stem cell transplantation in patients with stiff person syndrome. Neurology. 2021;96:e817-30.

45. Burt RK, Balabanov R, Han X, Burns C, Gastala J, Jovanovic B, et al. Autologous nonmyeloablative hematopoietic stem cell transplantation for neuromyelitis optica. Neurology. 2019;93: e1732-41. https://doi.org/10.1212/WNL.0000000000008394.

46. Greco R, Bondanza A, Oliveira MC, Badoglio M, Burman J, Piehl F, et al. Autologous hematopoietic stem cell transplantation in neuromyelitis optica: a registry study of the EBMT Autoimmune Diseases Working Party. Mult Scler. 2015;21:189-97. https://doi.org/10.1177/1352458514541978.
47. Ardura M, Hartley D, Dandoy C, Lehmann L, Jaglowski S, Auletta JJ, et al. Addressing the impact of the Coronavirus Disease 2019 (COVID-19) pandemic on hematopoietic cell transplantation: learning networks as a means for sharing best practices. Biol Blood Marrow Transpl. 2020;26:e147-60. https:// doi.org/10.1016/j.bbmt.2020.04.018.

48. Zamperlini-Netto G, Fernandes JF, Garcia JL, Ribeiro AAF, Camargo LFA, de Moraes Terra C, et al. COVID-19 after hematopoietic stem cell transplantation: report of two children. Bone Marrow Transpl. 2021;56:713-5. https://doi.org/10.1038/ s41409-020-01041-8.

49. Yates M, Watts RA, Bajema IM, Cid MC, Crestani B, Hauser T, et al. EULAR/ERA-EDTA recommendations for the management of ANCA-associated vasculitis. Ann Rheum Dis. 2016;75:1583-94. https://doi.org/10.1136/annrheumdis-2016209133.

50. Fanouriakis A, Kostopoulou M, Alunno A, Aringer M, Bajema I, Boletis JN, et al. 2019 update of the EULAR recommendations for the management of systemic lupus erythematosus. Ann Rheum Dis. 2019;78:736-45. https://doi.org/10.1136/a nnrheumdis-2019-215089.

51. Fanouriakis A, Kostopoulou M, Cheema K, Anders HJ, Aringer M, Bajema I, et al. 2019 Update of the Joint European League Against Rheumatism and European Renal Association-European Dialysis and Transplant Association (EULAR/ERA-EDTA) recommendations for the management of lupus nephritis. Ann Rheum Dis. 2020;79:713-23. https://doi.org/10.1136/a nnrheumdis-2020-216924.

52. Smolen JS, Landewe RBM, Bijlsma JWJ, Burmester GR, Dougados M, Kerschbaumer A, et al. EULAR recommendations for the management of rheumatoid arthritis with synthetic and biological disease-modifying antirheumatic drugs: 2019 update. Ann Rheum Dis. 2020;79:685-99. https://doi.org/10.1136/a nnrheumdis-2019-216655.

53. Kowal-Bielecka O, Fransen J, Avouac J, Becker M, Kulak A, Allanore Y, et al. Update of EULAR recommendations for the treatment of systemic sclerosis. Ann Rheum Dis. 2017;76:1327-39. https://doi.org/10.1136/annrheumdis-2016-209909.

54. Burt RK, Shah SJ, Dill K, Grant T, Gheorghiade M, Schroeder J, et al. Autologous non-myeloablative haemopoietic stem-cell transplantation compared with pulse cyclophosphamide once per month for systemic sclerosis (ASSIST): an open-label, randomised phase 2 trial. Lancet. 2011;378:498-506. https://doi.org/ 10.1016/S0140-6736(11)60982-3.

55. van Laar JM, Farge D, Sont JK, Naraghi K, Marjanovic Z, Larghero J, et al. Autologous hematopoietic stem cell transplantation vs intravenous pulse cyclophosphamide in diffuse cutaneous systemic sclerosis: a randomized clinical trial. JAMA. 2014;311:2490-8. https://doi.org/10.1001/jama.2014.6368.

56. Sullivan KM, Goldmuntz EA, Furst DE. Autologous stem-cell transplantation for severe scleroderma. $\mathrm{N}$ Engl $\mathrm{J}$ Med. 2018;378:1066-7. https://doi.org/10.1056/NEJMc1801275.

57. Di Benedetto P, Ruscitti P, Cipriani P, Giacomelli R. Haematopoietic stem cell transplantation in systemic sclerosis: challenges and perspectives. Autoimmun Rev. 2020;19:102662. https://doi.org/10.1016/j.autrev.2020.102662.

58. Falagas ME, Manta KG, Betsi GI, Pappas G. Infection-related morbidity and mortality in patients with connective tissue diseases: a systematic review. Clin Rheumatol. 2007;26:663-70. https://doi.org/10.1007/s10067-006-0441-9.

59. Furer V, Rondaan C, Heijstek M, van Assen S, Bijl M, AgmonLevin $\mathrm{N}$, et al. Incidence and prevalence of vaccine preventable infections in adult patients with autoimmune inflammatory rheumatic diseases (AIIRD): a systemic literature review informing the 2019 update of the EULAR recommendations for 
vaccination in adult patients with AIIRD. RMD Open. 2019;5: e001041. https://doi.org/10.1136/rmdopen-2019-001041.

60. Benoy S, Traksel R, Verhaegh P, Broen J. COVID-19 in rheumatology outpatient clinics: Dutch mirror image to Lombardy, Italy. Ann Rheum Dis. 2020;annrheumdis-2020-217765. https:// doi.org/10.1136/annrheumdis-2020-217765.

61. Haberman R, Axelrad J, Chen A, Castillo R, Yan D, Izmirly P, et al. Covid-19 in immune-mediated inflammatory diseasescase series from New York. N Engl J Med. 2020;383:85-88. https://doi.org/10.1056/NEJMc2009567.

62. Gianfrancesco M, Hyrich KL, Al-Adely S, Carmona L, Danila MI, Gossec L, et al. Characteristics associated with hospitalisation for COVID-19 in people with rheumatic disease: data from the COVID-19 Global Rheumatology Alliance physicianreported registry. Ann Rheum Dis. 2020;79:859-66. https://doi. org/10.1136/annrheumdis-2020-217871.

63. Zen M, Fuzzi E, Astorri D, Saccon F, Padoan R, Ienna L, et al. SARS-CoV-2 infection in patients with autoimmune rheumatic diseases in northeast Italy: a cross-sectional study on 916 patients. J Autoimmun. 2020;112:102502. https://doi.org/10. 1016/j.jaut.2020.102502.

64. Monti S, Balduzzi S, Delvino P, Bellis E, Quadrelli VS, Montecucco C. Clinical course of COVID-19 in a series of patients with chronic arthritis treated with immunosuppressive targeted therapies. Ann Rheum Dis. 2020;79:667-8. https://doi.org/10. 1136/annrheumdis-2020-217424.

65. FRSSSCI consortium and contributors. Severity of COVID-19 and survival in patients with rheumatic and inflammatory diseases: data from the French RMD COVID-19 cohort of 694 patients. Ann Rheum Dis. 2020;80:527-38. https://doi.org/10. 1136/annrheumdis-2020-218310.

66. Papa ND, Sambataro G, Minniti A, Maglione W, Pignataro F, Caminati A, et al. Impact of COVID-19 outbreak in an Italian cohort of patients with systemic sclerosis. Ther Adv Musculoskelet Dis. 2020;12:1759720X20953356. https://doi.org/10. 1177/1759720X20953356.

67. Strangfeld A, Schafer M, Gianfrancesco MA, Lawson-Tovey S, Liew JW, Ljung L, et al. Factors associated with COVID-19related death in people with rheumatic diseases: results from the COVID-19 Global Rheumatology Alliance physician-reported registry. Ann Rheum Dis. 2021; annrheumdis-2020-219498. https://doi.org/10.1136/annrheumdis-2020-219498.

68. Landewe RB, Machado PM, Kroon F, Bijlsma HW, Burmester GR, Carmona L, et al. EULAR provisional recommendations for the management of rheumatic and musculoskeletal diseases in the context of SARS-CoV-2. Ann Rheum Dis. 2020;79:851-8. https://doi.org/10.1136/annrheumdis-2020-217877.

69. Mikuls TR, Johnson SR, Fraenkel L, Arasaratnam RJ, Baden LR, Bermas BL, et al. American College of Rheumatology Guidance for the management of rheumatic disease in adult patients during the COVID-19 pandemic: version 2. Arthritis Rheumatol. 2020;72:e1-12. https://doi.org/10.1002/art.41437.

70. Torres J, Bonovas S, Doherty G, Kucharzik T, Gisbert JP, Raine $\mathrm{T}$, et al. ECCO Guidelines on therapeutics in Crohn's disease: medical treatment. J Crohns Colitis. 2020;14:4-22. https://doi. org/10.1093/ecco-jcc/jjz180.

71. SECURE-IBD Database. https://covidibd.org/. Accessed 5 May 2020.

72. Attauabi M, Poulsen A, Theede K, Pedersen N, Larsen L, Jess T et al. Prevalence and outcomes of COVID-19 among patients with inflammatory bowel disease-a Danish prospective population-based cohort study. J Crohns Colitis. 20216;15:54050. https://doi.org/10.1093/ecco-jcc/jjaa205.

73. Huang C, Wang Y, Li X, Ren L, Zhao J, Hu Y, et al. Clinical features of patients infected with 2019 novel coronavirus in
Wuhan, China. Lancet. 2020;395:497-506. https://doi.org/10. 1016/S0140-6736(20)30183-5.

74. Ungaro RC, Brenner EJ, Gearry RB, Kaplan GG, Kissous-Hunt $\mathrm{M}$, Lewis JD, et al. Effect of IBD medications on COVID-19 outcomes: results from an international registry. Gut. 2021;70:725-32. https://doi.org/10.1136/gutjnl-2020-322539.

75. Queiroz NSF, Regueiro M. Safety considerations with biologics and new inflammatory bowel disease therapies. Curr Opin Gastroenterol. 2020;36:257-64. https://doi.org/10.1097/MOG. 0000000000000607.

76. Magro F, Rahier JF, Abreu C, MacMahon E, Hart A, van der Woude CJ, et al. Inflammatory Bowel Disease Management during the COVID-19 outbreak: the ten do's and don'ts from the ECCO-COVID Taskforce. J Crohns Colitis. 2020;14:S798-806. https://doi.org/10.1093/ecco-jcc/jjaa160.

77. Brownlee W, Bourdette D, Broadley S, Killestein J, Ciccarelli O. Treating multiple sclerosis and neuromyelitis optica spectrum disorder during the COVID-19 pandemic. Neurology. 2020;94:949-52. https://doi.org/10.1212/WNL.0000000000009507.

78. Sullivan M, Bouffet E, Rodriguez-Galindo C, Luna-Fineman S, Khan MS, Kearns P, et al. The COVID-19 pandemic: a rapid global response for children with cancer from SIOP, COG, SIOP-E, SIOP-PODC, IPSO, PROS, CCI, and St Jude Global. Pediatr Blood Cancer. 2020;67:e28409. https://doi.org/10.1002/ pbc. 28409.

79. Liang W, Guan W, Chen R, Wang W, Li J, Xu K, et al. Cancer patients in SARS-CoV-2 infection: a nationwide analysis in China. Lancet Oncol. 2020;21:335-7. https://doi.org/10.1016/ S1470-2045(20)30096-6.

80. Pockley AG, Lindsay JO, Foulds GA, Rutella S, Gribben JG, Alexander $\mathrm{T}$, et al. Immune reconstitution after autologous hematopoietic stem cell transplantation in Crohn's disease: current status and future directions. A review on behalf of the EBMT Autoimmune Diseases Working Party and the Autologous Stem Cell Transplantation In Refractory CD-Low Intensity Therapy Evaluation Study Investigators. Front Immunol. 2018;9:646. https://doi.org/10.3389/fimmu.2018.00646.

81. Jeyanathan M, Afkhami S, Smaill F, Miller MS, Lichty BD, Xing Z. Immunological considerations for COVID-19 vaccine strategies. Nat Rev Immunol. 2020;20:615-32. https://doi.org/ 10.1038/s41577-020-00434-6.

82. https://www.who.int/publications/m/item/draft-landscape-ofcovid-19-candidate-vaccines. Accessed 11 Dec 2020.

83. Zhao J, Yuan Q, Wang H, Liu W, Liao X, Su Y, et al. Antibody responses to SARS-CoV-2 in patients of novel coronavirus disease 2019. Clin Infect Dis. 2020;71:2027-34. https://doi.org/10. 1093/cid/ciaa344.

84. Grifoni A, Weiskopf D, Ramirez SI, Mateus J, Dan JM, Moderbacher CR, et al. Targets of T cell responses to SARS-CoV-2 Coronavirus in humans with COVID-19 Disease and unexposed individuals. Cell. 2020;181:1489-501.e15. https://doi.org/10. 1016/j.cell.2020.05.015.

85. Sekine T, Perez-Potti A, Rivera-Ballesteros O, Stralin K, Gorin $\mathrm{JB}$, Olsson A, et al. Robust $\mathrm{T}$ cell immunity in convalescent individuals with asymptomatic or mild COVID-19. Cell. 2020;183:e114. https://doi.org/10.1016/j.cell.2020.08.017.

86. Cordonnier C, Einarsdottir S, Cesaro S, Di Blasi R, Mikulska M, Rieger C, et al. Vaccination of haemopoietic stem cell transplant recipients: guidelines of the 2017 European Conference on Infections in Leukaemia (ECIL 7). Lancet Infect Dis. 2019;19: e200-12. https://doi.org/10.1016/S1473-3099(18)30600-5.

87. Rubin LG, Levin MJ, Ljungman P, Davies EG, Avery R, Tomblyn M, et al. 2013 IDSA clinical practice guideline for vaccination of the immunocompromised host. Clin Infect Dis. 2014;58:309-18. https://doi.org/10.1093/cid/cit816. 
88. ASH-ASTCT. COVID-19 and vaccines: frequently asked questions (Version 1.0; last updated October 27). https://www.hema tology.org/covid-19/ash-astct-covid-19-and-vaccines\#.

89. Ljungman P, Avetisyan G. Influenza vaccination in hematopoietic SCT recipients. Bone Marrow Transpl. 2008;42:637-41. https://doi.org/10.1038/bmt.2008.264.

90. Unger JM, Blanke CD, LeBlanc M, Hershman DL. Association of the Coronavirus Disease 2019 (COVID-19) outbreak with enrollment in cancer clinical trials. JAMA Netw Open. 2020;3: e2010651. https://doi.org/10.1001/jamanetworkopen.2020.10651.

91. Waghmare A, Abidi MZ, Boeckh M, Chemaly RF, Dadwal S, El Boghdadly Z, et al. American Society for Transplantation and Cellular Therapy: guidelines for COVID-19 management in hematopoietic cell transplantation and cellular therapy recipients. Biol Blood Marrow Transpl. 2020;26:P1983-94. https://doi.org/ 10.1016/j.bbmt.2020.07.027.

92. Lupo-Stanghellini MT, Messina C, Marktel S, Carrabba MG, Peccatori J, Corti C, et al. Following-up allogeneic transplantation recipients during the COVID-19 pandemic. Lancet Haematol. 2020;7:e564-5. https://doi.org/10.1016/S2352-3026(20)30176-9.

93. Penedo FJ, Oswald LB, Kronenfeld JP, Garcia SF, Cella D, Yanez B. The increasing value of eHealth in the delivery of patient-centred cancer care. Lancet Oncol. 2020;21:e240-51. https://doi.org/10.1016/S1470-2045(20)30021-8.

94. Jain A, Chaurasia R, Sengar NS, Singh M, Mahor S, Narain S. Analysis of vitamin D level among asymptomatic and critically ill COVID-19 patients and its correlation with inflammatory markers. Sci Rep. 2020;10:20191. https://doi.org/10.1038/ s41598-020-77093-z.

95. Network NCC. NCCN hematopoietic growth factors, short-term recommendations specific to issues with COVID-19 (SARSCoV-2). Supportive care. https://www.nccn.org/covid-19/.

96. Pereira MR PSM, Scully B. Infections in allogeneic stem cell transplantation. In: Principles and practice of transplant infectious diseases. New York, NY: Springer; 2019. https://doi.org/ 10.1007/978-1-4939-9034-4_11.

97. Tomblyn M, Chiller T, Einsele H, Gress R, Sepkowitz K, Storek $\mathrm{J}$, et al. Guidelines for preventing infectious complications among hematopoietic cell transplantation recipients: a global perspective. Biol Blood Marrow Transpl. 2009;15:1143-238. https://doi.org/10.1016/j.bbmt.2009.06.019.

98. Muraro PA, Douek DC, Packer A, Chung K, Guenaga FJ, Cassiani-Ingoni R, et al. Thymic output generates a new and diverse TCR repertoire after autologous stem cell transplantation in multiple sclerosis patients. J Exp Med. 2005;201:805-16. https://doi.org/10.1084/jem.20041679.

99. Farge D, Arruda LC, Brigant F, Clave E, Douay C, Marjanovic $\mathrm{Z}$, et al. Long-term immune reconstitution and $\mathrm{T}$ cell repertoire analysis after autologous hematopoietic stem cell transplantation in systemic sclerosis patients. J Hematol Oncol. 2017;10:21. https://doi.org/10.1186/s13045-016-0388-5.

100. Bosch M, Khan FM, Storek J. Immune reconstitution after hematopoietic cell transplantation. Curr Opin Hematol. 2012;19:324-35. https://doi.org/10.1097/MOH.0b013e328353bc7d.

\section{Affiliations}

Raffaella Greco $\mathbb{( i D}^{1} \cdot$ Tobias Alexander $\mathbb{1}^{2} \cdot$ Joachim Burman $\mathbb{1}^{3} \cdot$ Nicoletta Del Papa ${ }^{4} \cdot$ Jeska de Vries-Bouwstra ${ }^{5}$. Dominique Farge $^{6,7,8} \cdot \mathrm{Jörg}_{\text {Henes }}{ }^{9}$ Majid Kazmi $^{10} \cdot$ Kirill Kirgizov $^{11}$ • Paolo A. Muraro $\mathbb{1}^{12}$ - Elena Ricart ${ }^{13,14}$. Montserrat Rovira ${ }^{15}$ - Riccardo Saccardi ${ }^{16}$ - Basil Sharrack ${ }^{17,18}$ - Emilian Snarski ${ }^{19,20,21}$ - Barbara Withers ${ }^{22}$. Helen Jessop ${ }^{23}$. Claudia Boglione ${ }^{16}$ - Ellen $\mathrm{Kramer}^{24} \cdot$ Manuela Badoglio $\mathbb{1}^{25} \cdot$ Myriam Labopin $\mathbb{1}^{25}$. Kim Orchard ${ }^{26}$. Selim Corbacioglu ${ }^{27}$. Per Ljungman $\mathbb{D}^{28} \cdot$ Malgorzata Mikulska ${ }^{29}$. Rafael De la Camara $\mathbb{D}^{30}$. John A. Snowden $\mathbb{1 0}^{23,31}$. On behalf of the European Society for Blood and Marrow Transplantation (EBMT) Autoimmune Diseases Working Party (ADWP), Infectious Diseases Working Party (IDWP), Pediatric Working Party (PWP), Joint Accreditation Committee of the International Society for Cellular Therapy (ISCT) and EBMT (JACIE), EBMT Nurses Group and Patient Advocacy Committee

1 Unit of Hematology and Bone Marrow Transplantation, IRCCS San Raffaele Scientific Institute, Vita-Salute San Raffaele University, Milan, Italy

2 Department of Rheumatology and Clinical Immunology, Charité Universitätsmedizin Berlin, Corporate Member of Freie Universität Berlin, Humboldt-Universität zu Berlin, and Berlin Institute of Health, Berlin, Germany

3 Department of Neuroscience, Uppsala University, Uppsala, Sweden

4 Scleroderma Clinic, Dip. Reumatologia, ASST G. Pini-CTO, Milan, Italy

5 Department of Rheumatology, Leiden University Medical Center, Leiden, The Netherlands

6 Centre de Référence des Maladies Auto-Immunes Systémiques Rares d'Ile-de-France, Filière, Paris, France

7 EA 3518, Université Denis Diderot, Paris, France
8 Department of Internal Medicine, McGill University, Montreal, QC, Canada

9 Department for Internal Medicine II (Oncology, Hematology, Rheumatology and Immunology), University Hospital Tuebingen, Tübingen, Germany

10 Kings Health Partners, Department of Haematology, Guys Hospital, London, UK

11 N.N. Blokhin National Medical Center of Oncology, Institute of Pediatric Oncology and Hematology, Moscow, Russia

12 Department of Brain Sciences, Imperial College London, London, UK

13 Inflammatory Bowel Disease Unit, Gastroenterology Department, Hospital Clinic of Barcelona, Barcelona, Spain

14 Institut d'Investigacions Biomèdiques August Pi i Sunyer (IDIBAPS), Centro de Investigación Biomédica en Red de Enfermedades Hepáticas y Digestivas (CIBERehd), Barcelona, Spain 
15 BMT Unit, Department of Haematology, Hospital Clinic, Institut d'Investigacions Biomèdiques August Pi i Sunyer (IDIBAPS); Institute Josep Carreras, Barcelona, Spain

16

Department of Haematology, Careggi University Hospital, Florence, Italy

17 Department of Neuroscience, Sheffield Teaching Hospitals NHS, Foundation Trust, Sheffield, UK

18 NIHR Neurosciences Biomedical Research Centre, University of Sheffield, Sheffield, UK

19 Department of Experimental and Clinical Physiology, Laboratory of Centre for Preclinical Research, Medical University of Warsaw, Warsaw, Poland

LUX MED Oncology, Warsaw, Poland

21

Polish Stem Cells Bank (PBKM), Warsaw, Poland

Department of Haematology and Bone Marrow Transplant, Sydney, Australia

23 Department of Haematology, Sheffield Teaching Hospitals NHS Foundation Trust, Sheffield, UK
24 Patient Advocacy Committee, EBMT Executive Office, Eddific Dr. Frederic, Duran i Jorda, Barcelona, Spain

25 EBMT Paris study office/CEREST-TC-Department of Haematology, Saint Antoine Hospital-INSERM UMR 938Université Pierre et Marie Curie, Paris, France

26 Department of Haematology, University Hospital Southampton and University of Southampton, Southampton, UK

27 Department of Pediatric Hematology, Oncology and Stem Cell Transplantation, University of Regensburg, Regensburg, Germany

28 Department of Cellular Therapy and Allogeneic Stem Cell Transplantation, Karolinska University Hospital Huddinge; Division of Hematology, Department of Medicine Huddinge Karolinska Institutet, Stockholm, Sweden

29 Division of Infectious Diseases, University of Genoa (DISSAL) and Ospedale Policlinico San Martino, Genoa, Italy

30 Department of Hematology, Hospital de la Princesa, Madrid, Spain

31 Department of Oncology and Metabolism, University of Sheffield, Sheffield, UK 